\title{
Factors Associated with Reporting of Sexual Assault among College and Non-College Women
}

\begin{tabular}{|r|l|}
\hline Journal: & Journal of Aggression, Conflict and Peace Research \\
\hline Manuscript ID & JACPR-05-2017-0298 \\
\hline Manuscript Type: & Empirical Paper \\
\hline Keywords: & $\begin{array}{l}\text { Sexual assault, Victimization, Violence against women, Rape, Police, } \\
\text { College }\end{array}$ \\
\hline \multicolumn{2}{|l}{} \\
\hline
\end{tabular}

\section{SCHOLARONE ${ }^{\text {w }}$ \\ Manuscripts}


Factors Associated with Reporting of Sexual Assault among College and Non-College Women

\section{Abstract}

Purpose - The purpose of this study is to examine factors impacting college and non-college women reporting sexual assault to police. Our goal is to increase knowledge regarding differences in the rates of reporting and reasons for reporting across these two groups.

Design/methodology/approach - Participants were drawn from a national telephone survey of U.S. women and a sample of U.S. college women. Bivariate and multivariate analyses were conducted to determine factors influencing the reporting of sexual assault to police. Findings - Non-college women were more likely than college women to report to police. Women who perceived their victimization as rape were much more likely to report to the police and women who had contact with a helping agency were also much more likely to report their assault. Contacting a helping agency is more relevant to non-college women's reporting to police, while considering the assault a rape is more important for college women.

Practical implications - Our results suggest that significant work is needed to encourage women in college to view sexual assaults as worthy of reporting. Boosting victim awareness and access to services is paramount. Providing psychoeducation to student victims to inform their perceptions about the definition of rape is vital, as women perceiving sexual assault as rape are more likely to report the incident.

Originality/value - Our research significantly adds to the literature indicating differences in rates of reporting and the factors that impact reporting uniquely for college versus non-college women. 
Keywords Sexual assault, Victimization, Violence against women, Rape

\section{Paper type Research paper}

7

8

9

10

11

12

13

14

15

16

17

18

19

20

21

22

23

24

25

26

27

28

29

30

31

32

33

34

35

36

37

38

39

40

41

42

43

44

45

46

47

48

49

50

51

52

53

54

55

56

57

58

59

60 
Sexual assault is a pervasive public health and safety issue for women in the United States. Although the risk of sexual assault is present for women at any life stage, women in college (typically between the ages of 18-24 years old) have particularly high rates of sexual assault (Fisher, Sloan, Cullen, and Lu, 1998). There may be unique risk and lifestyle factors such as excessive drinking and risky sexual behavior - for women in college, which may increase their risk of sexual victimization (Fisher et al., 1998). According to the Rape, Abuse, and Incest National Network (RAINN, 2016), women between the ages of 18-24 are at an increased risk for sexual violence. When compared with statistics for sexual violence for all women collectively, 18-24 year old women in college are three times more likely to experience sexual violence, and 18-24 year old women not in college are four times more likely to experience sexual violence. Despite their higher risk of sexual assault, however, college women are less likely to report the incident to the police (RAINN, 2016; Sinozich and Langton 2014; Wolitzky-Taylor et al. 2011b). According to the National Crime Victimization Survey (NCVS), among females ages 18 to 24 , approximately $32 \%$ of nonstudents report sexual assault victimization compared to $20 \%$ of college students (RAINN, 2016; Sinozich and Langton 2014). This discrepancy exists even though the percent of sexual assaults involving an acquaintance and involving a weapon are the same between the two groups (Sinozich and Langton 2014). There are several reasons why victims of sexual assault fail to report the incident to the police. According to recent statistics for women ages $18-24,26 \%$ of students and $23 \%$ of non-students believed it to be a personal matter, $20 \%$ of both students and non-students feared reprisal. more college victims, $12 \%$ of students and $19 \%$ of non-students believed their victimization was not important enough to report, $10 \%$ of students and $14 \%$ of non-students did not want to get their perpetrator in 
trouble, and $9 \%$ of students and $10 \%$ of non-students believed the police would not or could not do anything to help (RAINN, 2016).

Institutions of higher education offer supports and resources for students impacted by sexual assault that may be unavailable for most non-college victims (e.g., women's centers, campus counseling centers, etc.). However, these resources do not result in higher rates of service utilization. Among $18-24$ year old females, only $16 \%$ receive assistance from victim service agencies (RAINN, 2016). Comparisons of reporting behaviors between college and noncollege women are rare. The purpose of this study is to examine factors that influence the likelihood that sexual assault victims report the incident to the police, paying special attention to the roles of perceptions of sexual assault and contact with other helping agencies among college and non-college women.

\section{Factors related to reporting sexual assaults among victims}

Given the pervasiveness of sexual assault among young women, researchers have investigated reporting practices, as well as factors that may influence the decision to report the assault to authorities. Reporting a sexual assault typically entails notifying police, campus authorities, or community agencies established to assist victims (Orchowski et al. 2009). It is important to understand the reasons for reporting or not reporting sexual assault events since higher rates of reporting can reduce the likelihood that offenders can repeat their crimes, and increase the likelihood that victims will receive needed services (Orchosski et al. 2009). Unfortunately, much sexual assault goes unreported to police, regardless of college status. According to the National Violence Against Women Survey (NVAWS), less than 20\% of 
sexual assaults are reported to law enforcement (Tjaden and Thoennes 2006). In their metaanalysis, Sabina and Ho (2014) found that rates of reporting sexual assault to police were uniformly low across studies (less than 13\%). In another investigation using NVAWS data, Tjaden and Thoennes (2006) found that only $19 \%$ of sexual assaults were reported to police, and that the reporter was oftentimes a family member or friend of the victim rather than the victim.

Several factors impact the likelihood of reporting a sexual assault to authorities. Sexual assaults are more likely to be reported to the police when they are more severe in nature, such as those involving weapons, physical force, or injury (Sabina and Ho 2014; Wolitzky-Taylor et al. 2011a), when the perpetrator is a stranger (Fisher et al. 2003), when the victim has a better memory of the event (Kilpatrick et al. 2007), and when the victim was not under the influence of substances (Kilpatrick et al. 2007; Krebs et al. 2007; Wolitzky-Taylor et al. 2011a). Additionally, victims who are seeking justice, who trust police and university officials, or desire services (e.g., physical exams and testing for disease, see Moore and Baker [Forthcoming]) are more likely to report the assault. Conversely, women with a history of sexual victimization are less likely to report to the police, and those who do report are more likely to tell to a friend or family member than a community agency or the police (Orchowski et al. 2009; Tjaden and Thoennes 2006; Wolitzky-Taylor et al. 2011a). Existing research on college women indicates that demographic characteristics such as age, race/ethnicity, year in school, and income are unrelated to help-seeking among sexual assault victims (Amstadter et al. 2010).

Uncertainty and confusion as to whether or not the sexual assault qualified as a crime serves as an additional barrier to reporting, as do fears that police will not perceive the assault 
to warrant reporting (Sabina and Ho 2014). Myths about sexual assault also impact reporting behaviors (Orchowski et al. 2013). For example, the belief that sexual assault is a crime typically perpetrated by strangers often results in victims of acquaintance rape believing that they will be held responsible for the incident, or that they will be blamed for their assault (Bridges and McGrail 1989; Dupuis and Clay 2013; Grubb and Harrower 2009; Lea 2007). Similarly, women assumed by others to be sexually promiscuous often receive the message that they may be blamed for their assault should they choose to report (Cohn et al. 2009; Heaven, Connors, and Pretorius 1998; Luginbuhl and Mullin 1981). Women consuming alcohol or other substances prior to or during their victimization often fear that their sexual assault will not be classified as a crime since they were under the influence of perception-altering substances (Littleton and Axsom 2003; Littleton et al. 2006; Littleton, Axsom, and Grills-Taquechel 2009; Littleton, Breitkopf, and Berenson 2008; Stormo, Lang, and Stritzke 1997). Relevant to the current study, all of these factors may influence the likelihood that a victim perceives the assault to be serious enough to warrant police intervention (i.e., reporting).

In fact, the most impactful barrier in reporting sexual assaults to police may be the victim's perception that the assault is not serious enough to report (Sabina and Ho 2014), which may be influenced by some of the above factors. To demonstrate, Orchowski et al. (2013) found that only $21 \%$ of assaulted women labeled their experience as sexual assault or as a crime, and Walsh et al. (2016) found much fewer women who labeled their sexual assault as rape when drugs or alcohol was involved (24\%) versus when force was involved (73\%). Several of the factors reviewed above that are associated with reporting of sexual victimization may be especially relevant to women in college, and thus may partially explain the lower likelihood of 
reporting behaviors among this group. Given their different circumstances, additional research is needed to examine differences between college and non-college victims in their perceptions of sexual assault as rape, as well as the impact of perceptions on likelihood of reporting.

\section{Current study}

This study examines the factors that influence sexual assault reporting among female victims of sexual assault. Bivariate differences were assessed across two variables: 1) educational status (college versus non-college women) and 2) perception as rape (women who perceived their sexual assault as rape versus women who did not). A multivariate regression model was then used to identify the factors that predict whether or not victims reported the assault to police. Due to sample size limitations, it was not possible to examine this question in separate regression models among college and non-college women.

\section{Method \\ Participants}

Data from two sources were utilized to ensure adequate samples of college and noncollege female victims of sexual assault. One group was part of a national telephone household sample of 3,001 U.S. women, and the other group consisted of 2,000 college women selected from a reasonably representative national list of women attending four-year colleges and universities in the United States. Interview protocols were identical across both data sources.

The first group originated from a national cross-section of 2,000 women aged 18-34 years plus a national cross-section of 1,000 women aged 35 years and older. Researchers used 
random-digital-dial (RDD) methodology for selecting these samples, which were geographically stratified (Kilpatrick et al. 2007) to ensure that regional distributions were proportionate to regional populations. This group included 218 women, 30 of whom were in college at the time they were interviewed. Due to the focus on differences across college and non-college women, the subsample was limited to women whose age of most recent or only victimization was between the ages of 17 and 23 (the typical age of college students in the United States).

The second group originated from a sample of 2000 college women recruited using the American Student List (ASL): the largest and most widely used list of college students in the United States (Kilpatrick et al. 2007). The sample was divided into nine geographic regions, and women were contacted in proportion to the U.S. Census representation of the population of college women in each region (Paul et al. 2013). Women ages 18 years and over were interviewed using a computer-assisted telephone interviewing (CATI) system. The sampling frame contained approximately 17,000 individuals, and was restricted to women attending four-year institutions of higher education. Women were sampled from 253 different colleges and universities in 47 different states (73.5\% response rate, Kilpatrick et al. 2007). The original sample included 2,001 survey respondents. The sample analyzed in the current study included 146 women. The age of most recent or only victimization for these women was between the ages of 17 and 23.

The total sample analyzed for the current study included 364 women, 176 of whom were enrolled in college at the time interview, and all of whom experienced sexual victimization during the ages of 17 and 23. The primary strength of this data is that all respondents answered 
the exact same questions, providing an optimal opportunity for comparing rates of reporting and reasons for reporting across college vs. non-college women.

\section{Measures}

Survey respondents provided information about their age, ethnicity (Hispanic/Latino = 1 , otherwise 0 ), race (non-white $=1$, white $=0$ ), and whether they were ever married (never married $=1$, otherwise 0$)$, level of education $\left(8^{\text {th }}\right.$ grade $=1$, some high school $=2$, high school graduate $=3$, some college $=4,4$-year college graduate $=5$, some graduate school $=6$, graduate degree $=7$ ), and household income (ranges from 1 to 8 , where $1=$ less than $\$ 10,000$ and $8=$ $\$ 200,000$ or more). If respondents were in college, they were asked to provide an estimate of their parents' or primary guardians' total household income in lieu of their own household income.

Rape was defined as penetration of the victim's vagina, mouth, or rectum without consent. If a respondent reported experiencing more than one victimization, she was asked to provide information relative to her most recent victimization. The data include a number of characteristics of the victimization that have been linked to reporting in the literature (Crawford, O’Dougherty Wright, and Birchmeier 2008; Kimble et al. 2008; Loughnan et al. 2013; Maurer and Robinson 2008; McCauley and Calhoun 2008; Mohler-Kuo et al. 2004). For example, respondents were asked if the perpetrator used force or threat of force, if the offender was an acquaintance, and if they were under the influence of drugs and/or alcohol at the time of the victimization (all dichotomous measures). Respondents provided information about previous sexual victimization (yes $=1$, no $=0$ ), age at the time of the victimization, 
contact with an agency that provides assistance to victims (yes $=1$, no $=0$ ), and remembering details of the event (not well at all $=1$, not so well $=2$, very well $=3$, extremely well $=4$ ).

The current study aims to address the literature gap relative to the impact of victim perceptions of sexual assault on reporting behaviors. Participants responded to the following question: "Looking back on what happened, which best describes how you felt about the incident?" Respondents who perceived the incident as a rape were coded " 1 " on this variable, while respondents who perceived the incident as some type of crime but not a rape, an unpleasant incident but not a crime, or "not sure" were coded " 0 ".

The dependent variable reflects whether or not the respondent or someone else reported the incident to the police $(1=$ reported; 0 = not reported).

\section{Results}

\section{Descriptive statistics}

Descriptive statistics are displayed in Table 1. Approximately $17 \%$ of respondents stated that they had sought help from an agency. Approximately $42 \%$ of women perceived the assault to be a rape. Only $13 \%$ of respondents indicated that police were contacted regarding the victimization in question.

TABLE 1 HERE

\section{Bivariate analyses}

Differences between college and non-college victims

Table 1 includes the results of chi-square tests and t-tests to compare mean differences between college versus non-college victims. Non-college victims were more likely to experience 
perpetrator force during their assault. College victims were more likely to be under the influence of alcohol or drugs at the time of their assault, and were more likely to have experienced previous victimization. Perceptions of victimization varied between college and non-college women in the sample. Over $50 \%$ of non-college women perceived their victimization as rape, whereas only $31.8 \%$ of college women perceived their victimization as rape. Almost twice as many non-college victims reported their victimization to the police $(17.6 \%)$ as compared to the college victims $(9.1 \%)$.

Perceiving victimization as rape

Respondents perceiving their incident as rape were older, had a lower household income, were less likely to be in college, and less likely to be never-married (Table 1 ). In cases where perpetrator force was used, respondents were more than $30 \%$ more likely to perceive the assault as rape. Victims who were under the influence at the time of the assault were significantly less likely to perceive the assault as rape. Respondents were more likely to perceive the assault as rape if they had been previously victimized, experienced vicarious victimization, had sought the help of an agency, and if they reported a better memory of the incident. Importantly, victims perceiving their assault as rape were more than six times more likely to report their assault to the police.

\section{Multivariate analyses}

Predictors of reporting to police 
As demonstrated in Table 2, women who were in college at time of the assault were more than four times less likely to report their victimization to the police $(\exp (\beta)=0.239)$. None of the characteristics of the victimization impacted reporting to police at a 0.05 level of significance. However, women who sought help from an agency such as a rape crisis center were more than five times more likely to call the police $(\exp (\beta)=5.182)$. Finally, victims perceiving the assault as rape were about six times more likely to report to police $(\exp (\beta)=$ 5.709).

\section{TABLE 2 HERE}

Because the effects of college attendance, perceptions that the assault was a rape, and contacting a help agency were strongly related to reporting to police, we further explored perceptions, help-seeking, and reporting among college and non-college women, separately, using chi-square analyses (not shown). We found that force was more strongly related to noncollege women's perceptions of rape than among college women $\left(\chi^{2}=29.96^{* * *}\right.$ and $8.25^{* *}$ respectively). Being under the influence at the time of the incident was more relevant to college women's perceptions that the assault was rape than among non-college women. Additionally, the effect of previous victimization on perceptions that the assault was a rape was more relevant for non-college women $\left(\chi^{2}=11.20^{* * *}\right)$ than college women ( $\chi^{2}$ not significant). Chi-square analyses were implemented to detect any systematic differences in the reasons why college and non-college women sought help from a service agency (a strong predictor of reporting to the police in our multivariate models), as this would again explain the differing reporting rates across the two groups. Interestingly, being under the influence of substances was equally related to contacting a helping agency among college and non-college 
women. The effects of prior victimization and use of force, however, were stronger for noncollege women's decisions to contact a helping agency relative to college women (both were nonsignificant for college women). However, the effect of perceiving the assault a rape was stronger for college women - 33\% of college women who considered the incident as a rape reached out to a helping agency, compared to $23 \%$ of non-college women $\left(\chi^{2}=15.06^{* * *}\right.$ versus

\section{$7.41 * *$ respectively).}

Finally, in our examination of reporting to the police, most importantly, we found that considering the assault a rape was more influential for college women's reporting to police than non-college women $\left(\chi^{2}=31.17 * * *\right.$ versus $9.36 * *$ respectively). Finally, $54 \%$ of non-college women who contacted a helping agency reported the assault to the police, compared to only $22 \%$ of college women.

\section{Discussion}

This study extends research exploring factors related to victim's perceptions of their sexual assault, and factors relating to reporting to police among college and non-college women. Compared to other recent studies (e.g. Orchowski et al. 2013), the sample in the current study exhibited a high rate of perceiving sexual victimization as rape (42\%). This may be attributed to different definitions of victimization, as the data used in the current study included only sexual assaults that involved penetration (vaginal, anal, or oral). The finding that police were contacted by only $13.5 \%$ of victims is an important research focus, as higher rates of reporting may reduce the likelihood that offenders can repeat their crimes, increase the 
likelihood that victims will receive needed services, and allow researchers to more fully understand the nature of sexual victimization for both college and non-college women.

The current study examined the factors that impact reporting of rape to police. Consistent with prior research (e.g., Sinozich and Langton 2014), we found that non-college women were more likely to report to police than college women. Women who perceived their victimization as rape were nearly six times more likely to report to the police. Moreover, women who had contact with a helping agency were over five times more likely to report to the police. When disaggregated by college versus non-college subsamples, we found that the effect of contacting a helping agency is more relevant to non-college women's reporting to police, while considering the assault a rape is more important to college women.

Our results point to important policy implications, particularly on college campuses. The rate of classifying experience(s) of sexual victimization as rape was higher (42\%) than figures found in other studies. Over half of the current sample (58\%) refrained from labeling their assault as rape, meaning that they were less likely to contact victim service agencies, resulting in lower rates of reporting to authorities. Fewer college women than non-college women perceived the assault as a rape ( $31 \%$ versus $51 \%$, respectively), and this was partially due to the impact of being under the influence (which had a stronger influence on college women's views of "rape"). However, considering the assault as a rape was a stronger influence on college women's likelihood of contacting a helping agency than for non-college women. Only $22 \%$ of college women who contacted a service agency reported the assault to police, while $54 \%$ of non-college women who consulted a service agency did so. The pattern of results suggests that considering the assault as a rape is more influential for college women's reporting behaviors - 
to helping agencies or the police - than it is for non-college women, while contacting a helping agency is more important to reporting to the police for non-college women. Our results suggest that significant work is needed to encourage women in college to view sexual assaults as worthy of reporting - to anyone (not just the police) - while getting non-college women to contact a helping agency may be more important for this group. The difference is in part because non-college women tend to view the assault as a rape more often than college women. Boosting victim awareness of and access to services is paramount. For both students and non-students, the accessibility of $24 / 7$ national crisis hotlines are imperative for immediate and confidential access to support. Some national hotlines work closely with local service providers, and can easily connect victims to in-person services in their area (RAINN, 2016).

Public education serves as an additional priority. The findings of this study suggest that providing psychoeducation to student victims to inform their perceptions about the definition of rape is vital, as women perceiving sexual assault as rape are more likely to report the incident. The Rape Abuse and Incest National Network (RAINN) asserts that public education can occur through a variety of mediums, including speakers bureaus, social media, and even depictions on network television (2016). In short, the more exposure young women have to accurate information about sexual assault (e.g., what constitutes sexual assault, current victim and reporting statistics, ways of reporting, etc.), the more likely they are to correctly classify their experience and to seek the assistance they need.

The main limitation of the current study is the risk of making causal inferences from cross-sectional data. The association between victims contacting helping agencies and increased perceptions of rape was interpreted in causal terms in the current study, although it 
is possible that the relationship operates in the reverse direction, with victims perceiving their assault as a rape being more likely to contact an agency. Future research on the relationships between victim perceptions, rates of victims contacting helping agencies, and rates of reporting to police should examine longitudinal data that ensure correct temporal ordering.

Another limitation is inadequate data on the type of helping agency contacted, and type of services received. For example, for college students who contacted an agency, it is unknown if that agency was affiliated with their college or university. For the purpose of this study, this was assumed to be the case. To fully understand the importance of contacting such agencies, additional data is needed to correctly identify the policies that will encourage the highest rates of reporting. An additional limitation concerns the restricted age range to include only traditional college students (typically between the ages 18-24). This age range certainly does not capture or represent all college women (nor their non-college cohorts), and future researchers may wish to broaden the inclusion criteria for age to ensure a more generalizable result.

We encourage future research to untangle the complex relationships between perceptions of rape and help-seeking behaviors, such as reporting sexual assaults to police or other agencies, among college and non-college women. It is possible that the supports and resources available on most college campuses (e.g., counseling centers, women's centers, etc.) eliminate the need for women to go directly to police, as the supports available to them function as liaisons with police. It is also likely that non-college women who reach out to a designated agency will receive information about what constitutes rape, which may result in a stronger likelihood of perceiving an assault as rape. Similar to supports on college campuses, 
staff at agencies in the community typically also serve as liaisons to police, potentially accounting for increases in police reports. Thus, the mechanisms by which college and noncollege women seek help in the aftermath of sexual assault may be different.

\section{References}

Acock, A., \& Ireland, N. (1983). Attribution of Blame in Rape Cases: The Impact of Norm Violation, Gender, and Sex-role Attitude. Sex Roles , 179-193.

American College Health Association. (2016). Retrieved from American College Health Association: http://www.acha.org/

Amstadter, A. B., Zinzow, H. M., McCauley, J. L., Strachan, M., Ruggiero, K. J., Resnick, H. S., \& Kilpatrick, D. G. (2010). Prevalence and Correlates of Service Utilization and HelpSeeking in a National College Sample of Femal Rape Victims. Journal of Anxiety Disorders, 900-902.

Bachman, R. (1998). The Factors Related to Rape Reporting Behavior and Arrest: New Evidence from the National Crime Victimization Survey. Criminal Justice and Behavior, 8-29.

Ben-David, S., \& Schneider, O. (2005). Rape Perceptions, Gender Role Attitudes, and VictimPerpetrator Acquaintance. Sex Roles, 385-399.

Black, M. C., Basil, K. C., Breiding, M. J., Smith, S. G., Walters, M. L., Merrick, M. T., . . . Stevens, M. R. (2011). The National Intimate Partner and Sexual Violence Survey (NISVS): 2010 Summary Report. Atlanta: National Center for Injury Prevention and Control, Centers for Disease Control and Prevention.

Bridges, J. S., \& McGrail, C. A. (1989). Attributions of Responsibility for Date and Stranger Rape. Sex Roles, 273-286.

Civic Nation. (2016, January 8). It's On Us. Retrieved from It's On Us: http://itsonus.org

Cohn, E. S., Dupuis, E. C., \& Brown, T. M. (2009). In the Eye of the Beholder: Do Behavior and Character Affect Victim and Perpetrator Responsibility for Acquaintance Rape? Journal of Applied Social Psychology, 1513-1535. 
Crawford, E., O’Dougherty Wright, M., \& Birchmeie, Z. R. (2008). Drug-facilitated Sexual Assault: College Women's Risk Perception and Behavioral Choices. Journal of American College Health, 261-272.

Deitz, S. R., Littman, M., \& Bentley, B. J. (1984). Attribution of Responsibility for Rape: The Influence of Observer Empathy, Victim Resistance, and Victim Attractiveness. Sex Roles, 261-280.

Dupain, M., \& Lombardi, J. A. (2014). Developing and implementing a sexual assault violence prevention and awareness campaign at a state-supported regional university. American Journal of Health Studies, 264-270.

Dupuis, E. C., \& Clay, J. A. (2013). The Role of Race and Respectability in Attributions of Responsibility for Acquaintance Rape. Violence and Victims, 1085-1095.

Federal Bureau of Investigation. (2015). Crime in the United States, 2014. Federal Bureau of Investigation.

Fedina, L., Holmes, J. L., \& Backes, B. L. (Forthcoming ). Campus Sexual Assault: A Systematic Review of Prevalence Research from 2000 to 2015. Trauma, Violence, \& Abuse.

Feldman-Summers, S., \& Lindner, K. (1976). Perceptions of Victims and Defendants in Criminal Assault Cases. Criminal Justice and Behavior, 135-150.

Fisher, B. S., Daigle, L. E., Culler, F. T., \& Turner, M. G. (2003). Reporting Sexual Victimization to the Police and Others: Results from a National-Level Study of College Women. Criminal Justice and Behavior, 6-38.

Fisher, B. S., Sloan, J. J., Cullen, F. T., \& Lu, C. (1998). Crime in the ivory tower: The level and sources of student victimization. Criminology, 671-710.

Fisher, B., Cullen, F., \& Turner, M. G. (2000). The Sexual Victimization of College Women: Findings from Two National-Level Studies. DC: National Institute of Justice and Bureau of Justice Statistics.

Green Dot, Et Cetera, Inc. (2010). What We're Doing. Retrieved from Live The Green Dot: https://www.livethegreendot.com/

Grubb, A. R., \& Harrower, J. (2009). Understanding Attribution of Blame in Cases of Rape: An Analysis of Participant Gender, Type of Rape, and Perceived Similarity to the Victim. Journal of Sexual Aggression, 63-81. 
Heaven, P. L., Connors, J., \& Pretorius, A. (1998). Victim Characteristics and Attribution of Rape Blame in Australia and South Africa. Journal of Social Psychology, 131-133.

Kanekar, S., Kolsawalla, M. B., \& D'Souza, A. (1981). Attribution of Responsibility to a Victim of Rape. British Journal of Social Psychology , 165-170.

Karjane, H., Fisher, B., \& Cullen, F. (2005). Sexual Assault On Campus: What Colleges and Universities Are Doing About It. DC: U.S. Department of Justice, Office of Justice Programs, National Institute for Justice.

Kilpatrick, D. G., Resnick, H. S., Ruggiero, K. J., Conoscenti, L. M., \& McCauley, J. (2007). DrugFacilitated, Incapacitated, and Forcible Rape: A National Study. DC: U.S. Department of Justice.

Kimble, M., Neacsiu, A. D., Flack, W. F., \& Horner, J. (2008). Risk of Unwanted Sex for College Women: Evidence for a Red Zone. Journal of American College Health, 331-338.

Krebs, C. P., Lindquist, C. H., Warner, T. D., Fisher, B. S., \& Martin, S. L. (2007). The Campus Sexual Assault (CSA) Study. DC: U.S. Department of Justice.

Lea, S. J. (2007). A Discursive Investigation into Victim Responsibility in Rape. Feminism \& Psychology, 495-514.

Littleton, H. L., \& Axsom, D. (2003). The Rape and Seduction Scripts of University Students: Implications for Rape Attributions and Unacknowledged Rape. Sex Roles, 465-475.

Littleton, H. L., Axsom, D., \& Grills-Taquechel, A. (2009). Sexual Assault Victims' Acknowledgment Status and Revictimization Risk. Psychology of Women Quarterly, 3442.

Littleton, H. L., Axsom, D., Breitkopf, C. R., \& Berenson, A. (2006). Rape Acknowledgment and Postassault Experiences: How Acknowledgment Status Relates to Disclosure, Coping, Worldview, and Reactions Received from Others. Violence and Victims, 761-778.

Littleton, H. L., Breitkopf, C. R., \& Berenson, A. B. (2008). Beyond the Campus: Unacknowledged Rape Among Low Income Women. Violence Against Women, 269-286.

Loughnan, S., Pina, A., Vasquez, E. A., \& Puvia, E. (2013). Sexual Objectification Increases Rape Victim Blame and Decreases Perceived Suffering. Psychology of Women Quarterly, 455461.

Luginbuhl, J., \& Mullin, C. (1981). Rape and Responsibility: How and How Much is the Victim Blamed? Sex Roles, 547-559. 
Maurer, T. W., \& Robinson, D. W. (2008). Effects of Attired, Alcohol, and Gender Perceptions on Date Rape. Sex Roles, 423-434.

McCart, M. R., Smith, D. W., \& Sawyer, G. K. (2010). Help-Seeking Among Victims of Crime: A Review of the Empirical Literature. Journal of Traumatic Stress, 198-206.

McCauley, J. L., \& Calhoun, K. S. (2008). Faulty Perceptions? The Impact of Binge Drinking History on College Women's Perceived Rape Resistance Efficacy. Addictive Behaviors, 1540-1545.

Messman-Moore, T. L., \& Brown, A. L. (2006). Risk Perception, Rape, and Sexual Revictimization: A Prospective Study of College Women. Psychology of Women Quarterly, 159-172.

Mohler-Kuo, M., Dowdall, G. W., Koss, M. P., \& Wechsler, H. (2004). Correlates of Rape While Intoxicated in a National Sample of College Women. Journal of Studies on Alcohol , 3745.

Moore, B. M., \& Baker, T. (Forthcoming). An Exploratory Examination of College Students' Likelihood of Reporting Sexual Assault to Police and University Officials: Results of a SelfReport Survey. Journal of Interpersonal Violence.

Orchowski, L. M., Meyer, D. H., \& Gidycz, C. A. (2009). College Women's Likelihood to Report Unwanted Sexual Experiences to Campus Agencies: Trends and Correlates. Journal of Aggression, Maltreatment, and Trauma, 839-858.

Orchowski, L. M., Untied, A. S., \& Gidycz, C. A. (2013). Factors Associated with College Women's Labeling of Sexual Victimization. Violence and Victims, 940-958.

Paul, L. A., Walsh, K., McCauley, J. L., Ruggiero, K. J., Resnick, H. S., \& Kilpatrick, D. G. (2013). College Women's Experience with Rape Disclosure: A National Study. Violence Against Women, 486-502.

RAINN. (2016). Campus Sexual Violence: Statistics. Retrieved from Campus Sexual Violence: Statistics: https://www.rainn.org/statistics/campus-sexual-violence

Sabina, C., \& Ho, L. Y. (2014). Campus and College Victim Responses to Sexual Assault and Dating Violence: Disclosure, Service Utilization, and Service Provision. Trauma, Violence, and Abuse, 201-226.

Sinovich, S., \& Langton, L. (2014). Rape and Sexual Assault Victimization Among College-Age Females, 1995-2013. DC: U.S. Department of Justice. 
Spohn, C., \& Tellis, K. (2011). Justice Denied? The Exceptional Clearance of Rape Cases in Los Angeles. Albany Law Review, 1379-1421.

Stormo, K. J., Lang, A. R., \& Stritzke, W. G. (1997). Attributions About Acquaintance Rape: The Role of Alcohol and Individual Differences. Journal of Applied Social Psychology, 279305.

Tjaden, P., \& Thoennes, N. (2006). Extent, Nature, and Consequences of Rape Victimization: Findings from the National Violence Against Women Survey. DC: U.S. Department of Justice.

Walsh, K., Zinzow, H. M., Badour, C. L., Ruggiero, K. J., Kilpatrick, D. G., \& Resnick, H. S. (2016). Understanding Disparities in Service Seeking Following Forcible Versus Drug- or AlcoholFacilitated/Incapacitated Rape. Journal of Interpersonal Violence, 2475-2491.

Walsh, W. A., Banyard, V. L., Moynihan, M. M., Ward, S., \& Cohn, E. S. (2010). Disclosure and Service Use on a College Campus After an Unwanted Sexual Experience. Journal of Trauma \& Dissociation, 134-151.

Wolitzky-Taylor, K. B., Resnick, H. S., Amstadter, A. B., McCauley, J. L., Ruggiero, K. J., \& Kilpatrick, D. G. (2011). Reporting Rape in a National Sample of College Women. Journal of American College Health, 582-587.

Wolitzky-Taylor, K. B., Resnick, H. S., McCauley, J. L., Amstadter, A. B., Kilpatrick, D. G., \& Ruggiero, K. J. (2011). Is Reporting of Rape on the Rise? A Comparison of Women With Reported Versus Unreported Rape Experiences in the National Women's StudyReplication. Journal of Interpersonal Violence, 807-832. 
2

3

4

5

6

8

10

11

12

13

14

15

16

17

18

19

20

21

22

23

24

25

26

27

28

29

30

31

32

33

34

35

36

37

38

39

40

41

42

43

44

45

46

47

48

49

50

51

52

53

54

55

56

57

58

59

60 
Table 1. Descriptive Statistics

\begin{tabular}{|c|c|c|c|c|c|c|c|}
\hline \multirow{3}{*}{ Control Variables } & \multirow[t]{3}{*}{ Mean or \% } & \multirow[t]{3}{*}{ SD } & \multirow[t]{3}{*}{ Range } & \multicolumn{4}{|c|}{ Mean or \% Differences } \\
\hline & & & & \multicolumn{2}{|c|}{ College } & \multicolumn{2}{|c|}{ Perceived as Rape } \\
\hline & & & & Yes & No & Yes & No \\
\hline Age & 26.66 & 8.76 & $18-63$ & 21.70 & $31.31 * * *$ & 28.38 & $25.42 * * *$ \\
\hline Education & 4.14 & 1.04 & $1-7$ & 4.06 & 4.21 & 4.14 & 4.13 \\
\hline Income & 4.24 & 2.00 & $1-8$ & 4.91 & $3.62 * * *$ & 3.83 & $4.54 * *$ \\
\hline Currently in college & $48.4 \%$ & & $0-1$ & $x$ & $x$ & $36.6 \%$ & $56.9 \% * * *$ \\
\hline Ethnicity (Hisp./Lat.) & $7.4 \%$ & & $0-1$ & $6.3 \%$ & $8.5 \%$ & $9.8 \%$ & $5.7 \%$ \\
\hline Race (non-white) & $11.8 \%$ & & $0-1$ & $10.2 \%$ & $13.3 \%$ & $12.4 \%$ & $11.4 \%$ \\
\hline Never married & $63.9 \%$ & & $0-1$ & $86.9 \%$ & $42.2 \% * * *$ & $54.2 \%$ & $71.0 \% * *$ \\
\hline \multicolumn{8}{|l|}{$\begin{array}{l}\text { Characteristics of } \\
\text { Victim/Victimization }\end{array}$} \\
\hline Force used & $61.2 \%$ & & $0-1$ & $55.7 \%$ & $66.3 \% *$ & $79.7 \%$ & $47.6 \% * * *$ \\
\hline $\begin{array}{l}\text { Offender was } \\
\text { acquaintance }\end{array}$ & $85.4 \%$ & & $0-1$ & $85.2 \%$ & $85.6 \%$ & $82.4 \%$ & $87.7 \%$ \\
\hline $\begin{array}{l}\text { Victim under the } \\
\text { influence }\end{array}$ & $71.5 \%$ & & $0-1$ & $79.9 \%$ & $63.8 \% * *$ & $56.2 \%$ & $82.8 \% * * *$ \\
\hline Vicarious victimization & $78.6 \%$ & & $0-1$ & $77.8 \%$ & $79.3 \%$ & $45.8 \%$ & $28.2 \% * *$ \\
\hline Previous victimization & $55.8 \%$ & & $0-1$ & $61.7 \%$ & $49.4 \% *$ & $67.3 \%$ & $47.4 \% * * *$ \\
\hline Memory of incident & 2.62 & 1.05 & $1-4$ & 2.61 & 2.62 & 2.90 & $2.42 * * *$ \\
\hline $\begin{array}{l}\text { Age at time of } \\
\text { victimization }\end{array}$ & 19.26 & 1.71 & $17-23$ & 18.77 & $19.72 * * *$ & 19.34 & 19.21 \\
\hline Reported to agency & $17.1 \%$ & & $0-1$ & $17.6 \%$ & $16.6 \%$ & $27.5 \%$ & $9.5 \% * * *$ \\
\hline Perceived as rape & $42.0 \%$ & & $0-1$ & $31.8 \%$ & $51.6 \% * * *$ & $x$ & $x$ \\
\hline \multicolumn{8}{|l|}{ Dependent Variable } \\
\hline Reported to police & $13.5 \%$ & & $0-1$ & $9.1 \%$ & $17.6 \% *$ & $26.1 \%$ & $4.3 \% * * *$ \\
\hline
\end{tabular}

${ }^{*} p<.05,{ }^{* *} p<.01, * * * p<.001$ 
Table 2. Logistic Regressions Predicting Reporting to Police

\begin{tabular}{|c|c|c|c|}
\hline & Coefficient & S.E. & $\operatorname{Exp}(\beta)$ \\
\hline Age & $-0.072 *$ & .036 & 0.930 \\
\hline Education & -0.297 & .194 & 0.743 \\
\hline Income & 0.175 & .113 & 1.119 \\
\hline Currently in college & $-1.433^{* *}$ & .518 & 0.239 \\
\hline Ethnicity (Hisp./Lat.) & -1.223 & .879 & 0.294 \\
\hline Race (non-white) & 0.193 & .565 & 1.213 \\
\hline Never married & -0.005 & .499 & 0.995 \\
\hline Force used & 0.505 & .566 & 1.657 \\
\hline Offender was acquaintance & -0.820 & .497 & 0.440 \\
\hline Victim under the influence & -0.437 & .480 & 0.646 \\
\hline Vicarious victimization & 0.248 & .548 & 1.281 \\
\hline Previous victimization & -0.176 & .449 & 0.839 \\
\hline Memory of incident & 0.102 & .204 & 1.108 \\
\hline Age at time of victimization & 0.086 & .118 & 1.090 \\
\hline Reported to agency & $1.645^{* * *}$ & .413 & 5.182 \\
\hline Perceived as rape & $1.742 * * *$ & .478 & 5.709 \\
\hline-2 Log-likelihood & \multicolumn{2}{|c|}{191.12} & \\
\hline Nagelkerke R-Square & \multicolumn{2}{|c|}{0.364} & \\
\hline
\end{tabular}

${ }^{*} p<.05,{ }^{* *} p<.01,{ }^{* * *} p<.001$ 